\title{
Citizenship Education and National Integration: The Imperative of Developing the Psyche
}

\author{
Etumudor, Monday \\ Department of History, \\ College of Education, Warri-Delta State, Nigeria
}

Doi:10.5901/ajis.2012.v2n5p179

Abstract

Nations work assiduously to knit the various groups making up the nation. Nigeria had to an extent tried in this vain to ensure the integration of its diverse peoples through formal and informal education of the citizenry. Efforts had been made to educate citizens of its value systems, rights and obligations, fuse the people and bring an understanding in other to attain the national goals. Despite the effort so far made very little had been achieved, even when enormous energies and resources had been expended. Rather than the education bringing about conducive society, it has produced a society where the unusual has become necessities. For example, unusual source of wealth, evil and crimes of all shades perpetrated and contrary to the national goals, thus leaving a dysfunctional society in a nation that is abundantly endowed with both human and natural resources. The author believes that since citizenship education could not impact much positively on the people, either because it has not been stressed adequately and because of the new age and its characteristics, there is the need to expand education to the education of the psyche. The psyche is the mind which if properly trained would shape the world positively as it could help in the building and delivery of public services with truth and honesty. It is believed that with adequate training of the psyche, selfism, pride, arrogance, avarice, moral vices which delimits individuals and leaders positive behaviour would be demolished greatly and the society set free from negative tendencies. The way out is through sound moral education, less emphasis on immediate and individual gains, educating the people of its past (History), and its value systems. Consequently, we have to ensure through education the true transformation of the individual psyche for the sake of the national psyche and attainment of national goals.

\section{Introduction}

In an attempt to ensure peace, development and progress, good governance, good behaviour, national integration and economic growth, emphasis had been placed on educating the citizenry through citizenship education. Citizenship education is intended to acquaint citizens (especially youths). Values of the society, their rights and obligations, fuse the diverse peoples and culture to bring an understanding among them, and to strive to attain the national goals. Assisted by the knowledge of history, citizenship education among others help citizens develop a sense of pride in the cultural past of his community and nation, acquire training in analytical thinking and problem solving and understand the past as a guide for the appreciation of the present etc (Etumudor, 2000: 1 and 8).

To integrate the people and maintain a conducive environment, Nigerian educational system had attempted to keep her citizens abreast with the need for societal peace and to produce self control, orderliness, obedience and capacity for co-operation, ... and most importantly the control of ones urges and appetites in accordance with the interest of others and the society at large (Etumudor, 2002:3).

Through citizenship education various codes of conduct which scrutinizes individual and group conduct, sets out acceptable mode of participation and modalities for social interaction had been taught. The government created by law the code of Conduct Bureau and Tribunal as in the 1979 and 1989 constitution of the Federal Republic of Nigeria signed into law by the Ibrahim Babangida's government as the "Code of Conduct Bureau and Tribunal Decree No. 1, 1989”, amended as Decree No. 5, of 1990. Its establishment was to instill high standard of morality in government business, ensure that the actions and behaviour of 
public officers conform to the highest standards of public morality and accountability. There is also the public compliant commission (OMBUDSMAN) aimed at promoting justice for the individual citizens without which there can hardly be any genuine peace and stability in a country as well as assisting individuals who cannot help themselves to get their rights for any injustice suffered (Etumudor, 2002:5).

In addition to these are the Independent Corrupt Practices and Other Related Offences (ICPC) and the Economic and Financial Crimes Commission (EFCC) established in 2000 and 2003 respectively. The ICPC is charged with the powers to receive and investigate complaints from members of the public of corrupt practices among public officers while the EFCC had wider powers including conducting investigation of crimes of financial and economic nature, including corruption, Money Laundering, Advance Fee Fraud (419), Bank Fraud, etc. both in the public and private sector and to arrest and prosecute perpetrators of such crimes (Eweremadu, 2010: 8,12).

Efforts has also been made to educate Nigerians of their cultures. Nigerian cultures are capable of ushering in social order and had formed a major crux of the school curriculum which had been relentlessly followed in the course of instruction in preparation of leaders for the future. In our varied cultures where some overlap are subsumed values such as hospitality, benevolence, obedience, respect for elders as well as order, truth, love for good and one another, properly defined source of wealth, sense of justice and service to the people and more. The culture also decry and abhore unusual source of wealth, evil, crimes of all kinds, immorality and other social vices. These are now the order of the day, a trend whose roots are becoming very permanent and dangerous. This goes contrary to the 1989 constitution which stated that, "the state shall protect, preserve and promote the Nigerian cultures which enhances human dignity..." (Constitution of the Federal Republic of Nigeria, 1999).

The 1989 constitution recommended as national ethnics, discipline, integrity, dignity of labour, social justice, religious tolerance, self-reliance and patriotism. This is also inbuilt in the school curriculum. Every Nigerian is to conform with it, but looking at events as they unfold today, it is very obvious that we disregard national ethics.

The $6+3+3+4$ system of education was intended to make the school system comprehensive, that is, "education for all", created to cater for the pupils diversified tastes through educational technology (Igwebuike, 1989:222-224). One of the national objectives of education is to help each child to rise to the highest level of his potentials as a human being (Akali, 2005:11). This has become imperative following the complexity of present day political manouvres overriding due processes.

The current school system promotes sense of individualism and personal achievement. This is in consonance with our private thinking about what the school must do for children. We look more onto what will be achieved like turning our children into First Class Accountants, Architects, Doctors, Computer Scientists etc. rather than developing them into citizens who would build the nation, maintain it, portray nationalistic tendencies and pride of the nation. Our basic interest is the social and esteemed class we will be selected into after education, as well as the riches that would follow. This is what we bargained for which has resulted into a fragile society infested with heinous and pernicious evils. Thus the situation produced an empty society mindless of productivity, maintenance culture, order and social efficiency as against humanity (Asiedu, 1984:57).

Education is "a development of the mind through initiation into public traditions which incorporate impersonal standards and which, if mastered, give a distinctive quality to life" (Asiedu, 1984:55). These qualities are found in values such as freedom, happiness, security, pleasure, equality, sense of accomplishment and a comfortable life, honesty, courage, independence etc. There is no doubt that our classrooms today indirectly eschew teachings of social values, where it does exist, the extent, commitment, seriousness and adherence to it are not commensurable to what is out there waiting to consume the child in reality. Out there, the collective values are surcharged by interest, group interest whose effect changes the contents the child had been equipped with as it alters the proper behaviour which influences the child in adult life. This 
explains why Ogbimi (2010:64) qualified our education as market education which do not promote matching talents and functions and one where youths want to study courses they think would enable them make a lot of money. Some no longer care about utilizing the skills and knowledge gained from his discipline but certain to be employed by institutions and establishments with satisfactory pay package.

In an attempt to produce good citizens morally trained for secured and happy life, parents, government, social agencies such as the church, mosque, school, and the press or communication medias had contributed a lot in this task. Yet all expended efforts to a great extent proves unfruitful. The failure to adhere has resulted in the Nigerian situation characterized by bad governance and leadership examples, intensified ethnic rivalry, increased and uncontrollable corruption, predatory leadership, bastardization of both human and material resources, destruction of right values, uncontrollable and unacceptable carefree life styles, increased criminality, reduced productivity, hunger and poverty and others.

\section{Educating the Citizens Psyche}

Where citizenship education fail to create a conducive atmosphere of peaceful co-existence and development emphasis has to shift to the education of the citizens psyche. The reasoning is that if citizenship education could not convince and convict Nigerians on the values of good life, training and development of individuals psyche may bring about the realization of this.

Psyche is the totality of the human mind, conscious, and unconscious which in the creek world was used as a synonym for the word soul. It is a persons inner character, containing their true thoughts and feelings as well as consisting of three units namely, the id (force or energy), ego (functional self) and superego (moral and ethical elements of the ego (https www. google. Com, Almaas). Today, it combines to mean mind and soul, including capacity for reflective thinking of things and occurrences. The psyche or mind relates to the mental abilities of a human, the will, intellect, wit, power of judgment, cogitation, separating capability, experiences, the ability to discover coherences and the communicative aspects of human being, like language. The psyche is accessed by the mind which itself can uncover the distortions of reality that psyche has adapted to. Again, the psyche gives a connective link between the physical (body) and the spiritual aspects (mind and soul) of the human being as well as a bridge between the separated bodies of all the many human beings alive at the same time. Being invisible, though part of the body, its effect influences the physical (www. Gordon praxis./en/mind psyche).

The psyche is the essence of humanity, its greatest instrument is an indefinable creative entity of enormous people, subtlety and power that eludes all attempts to explain it. In psychology, the psyche is the centre of thought, feeling and motivation, consciously and unconsciously directing the body's reactions to its social and physical environment. It is also emotional.

Within the mind human final policies and decisions are conceived before execution. This confirms the creative entity, subtle and powerful nature of the psyche. It creates reality everyday and looks like it extends its tentacles out into the world and arranges, configures, and organizes the world so that it becomes the very medium through which the psyche is simultaneously expressing, embodying and revealing itself. Thus has a pre-eminent place in the natural order of things. Just as life fills the whole earth with plant and animal forms, so the psyche creates an even vaster world, namely consciousness, which is the self-cognition of the universe (Awakenin the dream, 2010).

From the above it is understood that the psyche has enormous influence in human life for its positive development, especially now that most people consider negative values as the very right values in the society. It is therefore, desirous that citizens are trained and equipped with the right psyche to conduct both individual and public lives. Working on the psyche entails making the leader at whatever level come to the understanding that leadership role is a call for service, based on the fact that the leader ought to be a servant 
of all. He is called to build and maintain the society, the body he is a part of. The purpose of the body is, the purpose of God Almighty.

The body has no independent purpose of its own. Leaders development therefore becomes essential in other to understand the national belief system. A belief is "a set of mutually supportive beliefs that may be religious, philosophical and ideological or a combination of these (and cultural (mine). A belief system also provide identity and govern thought, choices, actions, output and outcomes, govern daily lives and the overall purpose of life (Garba, 2012:21, 22, 24). This stand to mean that the psyche has to be trained to operate in line with the belief systems that are found in our institutions and organizations. These include formal rules, like the constitution and informal rules which include conventions, norms of social conducts and enforcement characteristics. Where a nation lack efficient, effective and imperial enforcement system she will not be capable of producing efficient, effective and just economic outcomes and in addition socio-political outcomes.

\section{Approaches to Psyche Education and Training}

Though the psyche exists on its own, it is not an island onto itself. It is acted upon by the environment which it also act back on. The way it acts on environment finalizes how the world of humanity is shaped. The psyche must be developed to the level where citizens begin to realize the need for truth and dedication in our actions and start involving in the building and delivery of public services, with honesty. In addition the development of the psyche of Nigerians is to fight selfism characterized by self-conceit (exaggerated opinion of oneself, pride, self-assertiveness (unwarranted), self-abandonment, self-indulgence, avarice, arrogance, lack of confidence, intolerance, moral delusion, sychophants, flatters and spies, tribalism and more. Below are examples of ways this author feel training of the psyche can come about.

\section{Moral Education}

The ground for moral obligation is based primarily on human well-being which incorporate the well-being of the society and the individual himself. Moral obligation is also intended for posterity. It is necessary to be morally upright in order to have a satisfactory human life, otherwise we shall be worse off (Oyeshile, 2002: 94, 96).

The psyche of both citizens and leaders deserve to be morally positioned to avoid national conflicts. It is the duty of the leader to ensure that the people live in peace. When a nation is peaceful, life would be led with ease and in fulfillment. The scene today is such that people are forced and pretend to live in peace when in reality conflict, envy, selfishness and other evil vices loom round them. This situation exists due to insensibility, insecurity and unconcerned attitude of leaders who had illegally gained the reigns of power and unknowledgeable about whom a leader is. A leader is someone who despite all the qualities of leadership possessed is a servant whose primary concerns are to attain the goals and objectives of his nation. For anyone to understand this, he must be morally balanced and equipped, that is rooted in the ethical values of the society as had been previously discussed.

\section{History Education}

Very obvious is the fact that history as an academic discipline witnessed serious challenges from skeptics who could neither understand how knowledge of what happened in the bygone age could be obtained nor see the significance of such knowledge in their contemporary times. We need to acknowledge that "the past is not an isolated entity completely cut off from the present, rather there exists a continuity between the two. It should be accepted therefore, that one of the essence of history is to provide insight into the background of the 
working of the contemporary society. Thus, an understanding of the past is important in understanding how the society reached the contemporary stage of development (Adediran, 2002: 2, 3, 4).

It is the attempt being made to accept, stick and rely on the modern that is tending to land the society into delusion. People could argue that it is impossible for the society to be destroyed. When a society is dysfunctional, it is sufficient to conclude that the society is without a psyche or soul or mind, thus without life. The only way to avoid such a pitfall is to anchor on the education of the individual psyche through value assessment and the history of the land. History primarily throw light on foregone periods that are still relevant for the resolution of grail areas of our daily life. This affirms Authur Marwick, who said, "to go all modern, and deny any value to the study of earlier history is in fact to deny the value of history all together (Adediran, 2002:5).

The disconnection from the past arises from want of self-independence and self-reliance which differ from the old African communal life-pattern. History has the capacity to glue the diverse peoples together by eliminating dividing lines in our relationships. This is so due to the fact that it is capable of creating an attitude of patriotism, implant moral values in the young, quicken the imaginative power of children for the understanding of the world around them. In addition, it helps people tolerate one another, provide understanding and solution to socio-political and economic problems, shape our knowledge, character and moral state so as to deal with ourselves to bring about co-existence, etc. A genuine study and reliance on the past could change attitudes as human understanding is moved by those events which strike the psyche most (Etumudor, 2002: 4 - 7).

Most leaders lacking historical knowledge of their land are not rooted in their past fail to realize the power of history to guide their actions. This exposes the extent to which we disregard our past. However, no matter the extent we rebel and repudiate history, it cannot be exorcised. It is in the mind and as it ticks it reminds us that we have not taking stock of what we know of the past events and meditating on what they mean to us today. This proves that the power of any culture to grow and add to itself lies in history and any that loses it soon dies. History is concerned with all that is memorable in the human past. Men need it for their edification and satisfaction of a certain urge in their beings. They would resort to it at crucial times of their lives even if they sometimes turn round to traduce or depreciate it (Akinola, 1993:2).

\section{Value Assessment}

The drive for myriads of unpopular needs such as ill-gotten wealth, power and fame have led to the disregard and abandonment of African and western value system which training in citizenship education have strived endlessly and relentless to inculcate on the citizenry. Such values are discipline, respect for one another/group, justice, kindness, humility, modesty, abstinence, moderation, integrity, honesty, service to community, consultation, advice, consent, obedience and more. These are to form the characteristics of expectant leaders.

This bring about value assessment, the basis on which a leader could be judged successful or unsuccessful. The leader who ignore the moral components of leadership may well go down in history as a scoundrel (Stoner, Freeman, Daniel, 2002:470). The leader must be sincere, a role model for the led to imitate and must also not be hypocritical. What then are values? They are "the highest ethical parameters, standards and criteria through which individual groups and societies order their goals, determine their choices and judge their conduct as they pertain to life both in private and public affairs. Value provide measurement for political, economic, social and other actions. Being psychic, values guide actions and are standards for evaluating actions. Thus these values are essential for good governance and social relations among the various peoples. Any leader who lack these will lack leadership skills and need not come close to positions of authority. This is the opposite today, hence the absence of the ideals of good governance. 


\section{Conclusion}

It is sad that all attempts at educating the citizenry towards the production of an integrated society had not yielded much positively. Rather than associate and relate effectively, the extent of our relations tend to divide us further. This is because very little had been done to understand and train the peoples psyche to utilize satisfactorily the national belief system, ethics and conventions.

This nation is richly endowed with both human and material resources, yet the people experience more hardship and separateness as well as the underutilization of the resources. However, this unsound state of affairs should not be allowed unabated.

We require and deserve true transformation of the citizens in the area of psyche for effective understanding of the society. The transformation has be spiritual and not material or physical. For it is the spiritual transformation that gives physical and material transformation its true character, form, true essence and true meaning.

True transformation begins with a transformed person and a transformed mind. This would lead to the understanding of leadership roles and good governance. The transformed mind will understand that if a nation lack efficient, effective and impartial enforcement systems it cannot produce efficient, effective and just leadership, just economic and socio-political outcomes, these could be attained when citizens realizes their history, national values and morals etc. which would guide one towards good governance and effective integration.

\section{References}

A.H. Almaas www.ahalmaas.com/glossary/psyche

Adediran, A.A. (2002): The Problem with the Past: An Inaugural Lecture Series. Obafemi Awolowo University, O.A.U. Press Limited, Ile-Ife, Nigeria.

Akali, R.T. (2005): "The Role of Parents in the Control and Prevention of Youth Violence in Nigeria". Zaria Journal of Educational Studies Vol. 7 No. 1 and 2.

Akinola, Akin (1993): "Who Needs The Past"? An Inquiry into the Meaning and Relevance of History in Ibadan Journal of Humanistic Studies No. 6. Ibadan: Ladi Printers.

Asiedu, K. (1984): Education and the Inculcation of Social Values in Aman Journal of Society, Culture and Environment. Vol. 3 No. 2. The Centre for Social, Cultural and Environmental Research. Uniben, Benin City.

Constitution of the Federal Republic of Nigeria 1999 Chapter II, Fundamental Objectives and Directive Principles of State Policy, No. 13, 14 and 15.

Etumudor, M. (2000): “The Role of History in Citizenship Education”. Conference Paper Presented at the Federal College of Education, Abeokuta.

Etumudor, M. (2002): "Engineering the Nigerian Society for Social Development". Conference Paper Presented at the 46th Congress of the Historical Society of Nigeria and the Dike Memorial Lecture/Awards of Honourary Fellowship.Theme: Historical Consciousness, Social Engineering and Nation-Building at Benue State University, (BSU) Makurdi.

Eweremadu, D.U. (2010): Anti-Corruption Policies in Nigeria under Obasanjo and Yar'Adua: What To Do After 2011. Friedrich Ebert Stiftung Publishers.

Garba, P.K. (2012): “The Impossibility of Sound Economic Outcomes without Sound Management and Leadership”. An Inaugural Lecture Series, University of Ibadan. Ibadan University Press.

https www.google.com, what is psyche

Igwebuike, T.B. (1989): "Educational Technology and the New Secondary School Systems in Nigeria". In Journal of Research in Education.

Ogbimi, F.E. (2010): Achieving Rapid Industrialization and Democratization in Africa: The Role of Education and Training. An Inaugural Lecture Series 245, Obafemi Awolowo University, Obafemi Awolowo University Press Limited, Ile-Ife, Nigeria. 
Oyeshile, A. Olatunji, (2002): "Morality and its Rationale: The Yoruba Example". In Ibadan Journal of Humanistic Studies Nos. 11 \& 12.

Stoner, James, Freeman, R.E. and Gilbert (2002): Management Sixth Edition. USA, Prentice Hall, Inc. Englewood Cliffs, New Jersey.

www.awakenin the dream.com/wordpress/the-world-is-psyche- 
